This item was submitted to Loughborough's Research Repository by the author.

Items in Figshare are protected by copyright, with all rights reserved, unless otherwise indicated.

\title{
Bridging Zambia's water service gap: NGO/community partnerships
}

PLEASE CITE THE PUBLISHED VERSION

http://www.icevirtuallibrary.com/content/serial/wama

\section{PUBLISHER}

(c) Institution of Civil Engineers

\section{VERSION}

VoR (Version of Record)

\section{LICENCE}

CC BY-NC-ND 4.0

\section{REPOSITORY RECORD}

Kayaga, Sam, and Cathryn Kadimba-Mwanamwambwa. 2019. "Bridging Zambia's Water Service Gap: Ngo/community Partnerships". figshare. https://hdl.handle.net/2134/9705. 
This item was submitted to Loughborough's Institutional Repository (https://dspace.lboro.ac.uk/) by the author and is made available under the following Creative Commons Licence conditions.

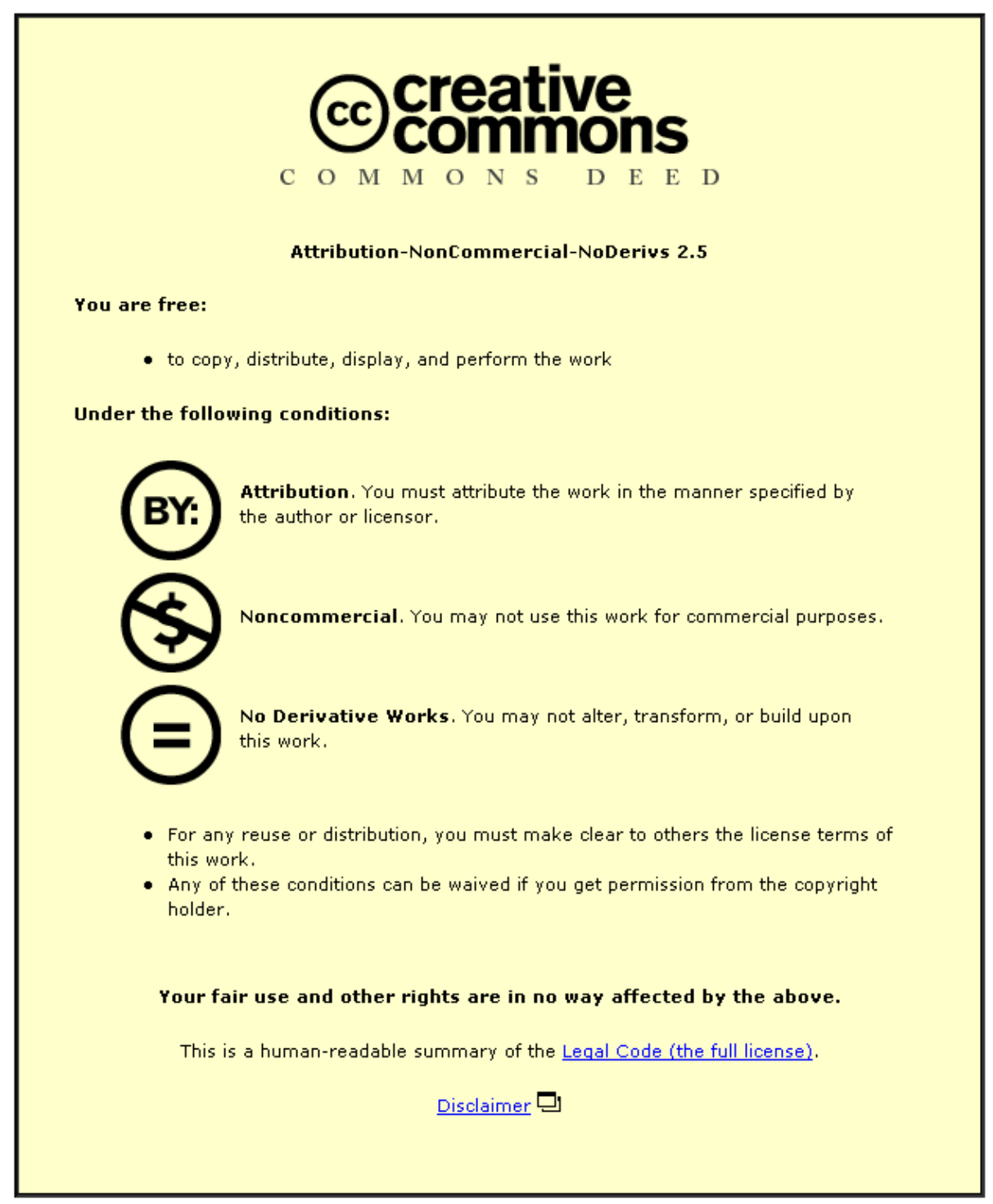

For the full text of this licence, please go to: http://creativecommons.org/licenses/by-nc-nd/2.5/ 


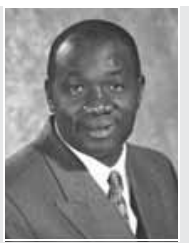

Sam Kayaga

Assistant Programme Manager, Water, Engineering and Development Centre WEDC), Loughborough University, UK

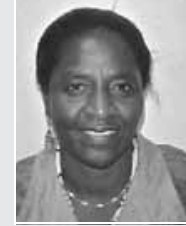

Cathryn Kadimba-Mwanamwambwa Director, Governance Sector, Care International Zambia, Lusaka, Zambia

\section{Bridging Zambia's water service gap: NGO/community}

\section{partnerships}

S. Kayaga MSc, PhD, CEng, MCIWEM and C. Kadimba-Mwanamwambwa DipEd, MSc

\begin{abstract}
Although the world's urban population has in the last $\mathbf{5 0}$ years increased fourfold, investment in water and sanitation services infrastructure in low-income countries has not kept pace with this population growth. Consequently, between 30 and $60 \%$ of the urban population is not adequately served. Invariably, poor people bear a disproportionate share of the impact of low service levels and are forced to adopt coping mechanisms, ranging from group connections to reliance on traditional water supply and sanitation systems, which are often technically unsuitable to the urban environment. This paper presents a case study in which CARE International set up an independent community-managed 'Water Trust' system to serve about 85000 people in Kanyama, a low-income settlement in Lusaka, Zambia. A recent evaluation study showed that, compared to services delivered by Lusaka Water and Sewerage Company, the legitimate water utility, the Water Trust system was delivering water services of better quality and in a cost-effective manner. Further study needs to be done on the optimum institutional arrangement to ensure that communities served by the Water Trust fully benefit from the regulatory regime currently taking a firm grip in Zambia.
\end{abstract}

\section{INTRODUCTION}

A key cross-cutting target of the global Millennium Development Goals is to halve the number of people without sustainable access to safe drinking water and basic sanitation by the year $2015{ }^{1}$ It was estimated that by the turn of the century, between 1.6 billion and $2 \cdot 2$ billion people, the majority of whom lived in developing countries, lacked access to safe drinking water and basic sanitation, respectively. ${ }^{2}$ Although more people in developing countries currently live in rural areas, the task of providing urban water services is equally challenging, given the high level of urbanisation in developing countries. Rural-urban migration in search of better livelihoods, coupled with internal population growth results in a situation where larger numbers of people compete for scarce and deteriorating resources within the expanding city limits. These immigrants, who are generally unskilled and low salaried, usually stay in informal/unplanned settlements.

According to the World Health Organisation (WHO)/UNICEF 2000 Joint Monitoring Programme, ${ }^{2} 27 \%$ and $18 \%$ of the population in
Africa and Asia respectively live in informal settlements of the cities. In most cases, these urban poor people cannot access benefits from piped water services, as there are hardly any piped water reticulation systems in these informal settlements. Consequently, residents of these low-income settlements usually receive poorer water services. In many countries, the urban poor resort to purchasing water from the more expensive water vendors, who supply water with doubtful technical quality. ${ }^{3}$ In response to the poor service levels, alternative non-utility providers have taken up the role of bridging gaps in the urban water service provision for low-income communities. There are two main types of alternative providers

(a) intermediate providers, who obtain water from a utility company's piped network and redistribute it either through network extensions in un-served areas, or carry it physically in containers to the customers' doorsteps

(b) independent providers, who develop alternative water sources such as boreholes, and distribute it, independently of the utility service provider, through a pipe network or a single supply point, to un-served areas.

In many cases, alternative service providers are private individuals or entities, who emerge spontaneously in response to local demand. In the recent past, some local and international non-governmental organisations (NGOs) have responded to the appalling situation in urban low-income settlements, and attempted to fill the gap. As a result, several models for service delivery and management for the urban poor have emerged. ${ }^{4}$ This paper presents findings of a case study carried out in Lusaka, Zambia where CARE International, an NGO in partnership with other stakeholders, has developed a 'Water Trust' model through which the capacity of local communities has been built to provide water services to six low-income settlements, to supplement services provided by Lusaka Water and Sewerage Company (LWSC), the utility service provider. The paper explores CARE's experience with the establishment of the Water Trust in Kanyama Settlement, an unplanned low-income settlement of approximately 145500 people. The fieldwork, which was carried out in July/August 2004, comprised key informant interviews and direct observations.

\section{CARE'S INTERVENTION}

Zambia is a landlocked sub-Saharan country whose population was estimated in 1996 to be 9.5 million people, 40\% of whom 
lived in urban areas. ${ }^{5}$ Lusaka, the country's capital city was estimated to have 1120000 people by 1996, of which 60\% lived in low-income settlements. Officially, provision of water and sanitation services in Lusaka City is the responsibility of LWSC, a private liability company that is wholly owned by Lusaka City Council. By the end of 2003, LWSC, which had 482 permanent staff, was producing an annual average of 76.2 million cubic metres of treated water, which it supplied through about 34500 water supply connections. In line with a national policy and action plan for delivery of water and sanitation services to peri-urban areas, also locally known as compounds, LWSC set up a peri-urban unit in 1995 to cater for the provision of services to an estimated 670000 people in Lusaka's informal settlements. ${ }^{6}$

In spite of the peri-urban policy, LWSC's service coverage was estimated at $34 \%$ of the population in Lusaka, people living in low-income settlements being most affected by the utility's poor service levels. ${ }^{7}$ Many residents of peri-urban areas spend lots of time collecting water, usually from shallow wells, which is often of poor bacteriological and physical-chemical quality, resulting in a high incidence of water-borne diseases. CARE International is one of the international NGOs that set up projects in Zambia in the early 1990s, to fill the urban water services gap. CARE's involvement in the peri-urban settlements of Lusaka and Livingstone cities started in 1992 and was in the form of mutually reinforcing project interventions in the fields of infrastructure improvement, environmental health, micro-finance and institution-building. Through two phases of Project Urban Self-Help (PUSH I and II), CARE aimed to improve the livelihood of residents in the lowest socio-economic strata through strengthening community-based organisations and improving the status of women; improving the physical infrastructure and environment of the settlements; and strengthening the capacity of Lusaka City Council to upgrade the slums.

PUSH I, which was implemented during 1992-1994, was mainly a food-for-work project that successfully transferred technical skills (e.g. road and drainage construction, brick moulding) to participating community members, 95\% of whom were women, leading to better food prospects for their households. This was followed by PUSH II (1994-1997), which concentrated on aspects of urban upgrading and community development. Under PUSH II, CARE also implemented a pilot community-managed water project in Chipata settlement, in which technical support was provided to the Resident Development Committee, the community-based organisation that managed the water system. Based on evaluation by Price Waterhouse Coopers consultants in 1999, CARE, working closely with key stakeholders, scaled up the Chipata experience into the 'Water Trust' model, under which independent water supply systems in the six settlements were subsequently managed by the communities.

The first year of PUSH II involved undertaking the participatory appraisal and needs assessment (PANA), which enabled CARE to gain a deeper understanding of the community needs in the settlements. The PANA process enabled a broad section of the community to participate in and engender ownership of the programme. Through the PANA process, the PUSH II project emphasised partnerships with Lusaka City Council and their lowest local structures, the area based organisations (ABOs), participation at household level, process-based approach and institutionalisation of monitoring and evaluation systems as well as gender mainstreaming. Through a series of zone-level meetings and focus group discussions, community members identified water supply as the most critical problem at both the household and settlement levels. This marked the beginning of CARE's direct involvement in construction of water supply infrastructure in Zambia.

In March 1998, CARE International, with funding obtained from the UK Department for International Development (DfID) built on the experiences of PUSH I and II to establish the Programme of Support for Poverty Elimination and Community Transformation (PROSPECT). To address the wider needs of the communities, PROSPECT comprised three interrelated components of institution strengthening, micro-finance and infrastructure improvement. Apart from provision of water infrastructure services, the scope of PROSPECT extended to the following interventions

\section{(a) social empowerment}

(b) governance issues

(c) piloting of Resident Development Committees, elected grass-root community representatives

(d) personal empowerment

(e) addressing household problems

$(f)$ encouraging new initiatives

(g) communal waterborne toilets at public places such as markets, which were passed over to Lusaka City Council for management of operation and maintenance

(h) household level solid waste management

(i) continuing with infrastructure improvement programmes.

The following section concentrates on aspects concerned with water supply services in Kanyama, one of the peri-urban settlements in Lusaka.

\section{KANYAMA WATER TRUST MANAGEMENT SYSTEM, A CASE STUDY}

Kanyama is one of the six peri-urban settlements in Lusaka where the Water Trust model has been scaled up. PROSPECT constructed the necessary infrastructure and empowered communities to manage all aspects of water service delivery to a section of the settlement covering a population of approximately 85000 people. In order to promote participation effectively at the grass-roots level, the settlement was demarcated into 30 zones, which were clustered into four sectors. These zones were organised into governance units, in which community members elected ten leaders, (five men and five women) known as the Zone Development Committees (ZDC). Each ZDC chose a delegate to the Residents Development Committee (RDC), a local governance structure legally recognised as the lowest structure of the Local Authority. In order to enhance community participation throughout the whole project cycle, volunteer community members were selected from each of the zones to conduct the PANA.

As a departure from previous CARE interventions in Zambia, the PROSPECT project aimed to make the water supply system sustainable, through cost recovery mechanisms, and yet fulfilling the objectives of social equity. Learning from the Chipata pilot experience, a substantial fraction of the project period was used to mobilise community members to participate physically in the project and to appreciate the importance of cost recovery. 


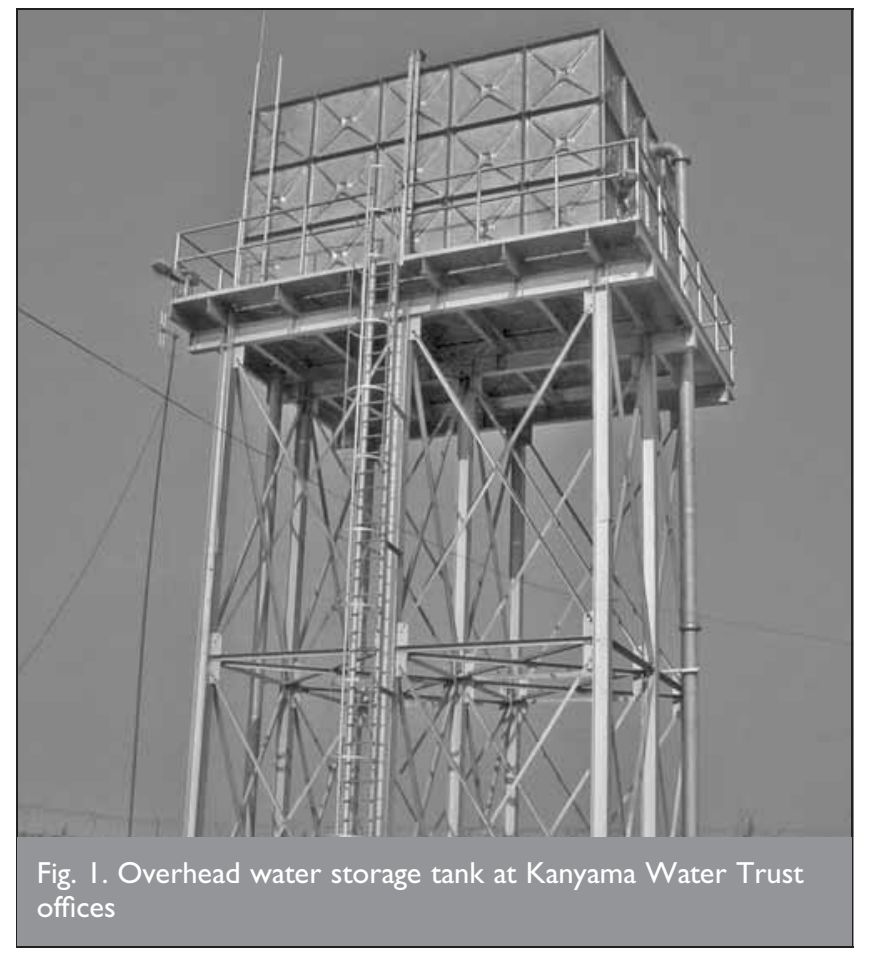

A phased approach was adapted, in which residents of the four sectors were involved in the project at different times. The project provided necessary materials and conducted elementary artisan training for community members, offering basic skills to enable effective participation by both women and men in tasks such as excavating/backfilling trenches, laying pipes and construction of water points to some minimum technical standard. However, other more technically complex tasks such as borehole siting/ drilling, pump installation and electrical wiring were contracted to specialised firms. Water is pumped from two boreholes, dozed with chlorine gas using online dozers, stored in overhead reservoirs and distributed by gravity. Figure 1 shows one of the overhead water reservoirs constructed under the project and Fig. 2 shows one of the public stand taps managed by Kanyama Water Trust.

The Water Trust management model was being developed as the installation of the water supply infrastructure progressed. The Water Trust is comprised of a two-tier management structure with the Board of Trustees as the apex body and the management team as the supporting structure. Figure 3 shows a schematic diagram of the Water Trust model. The Board of Trustees is composed of nine

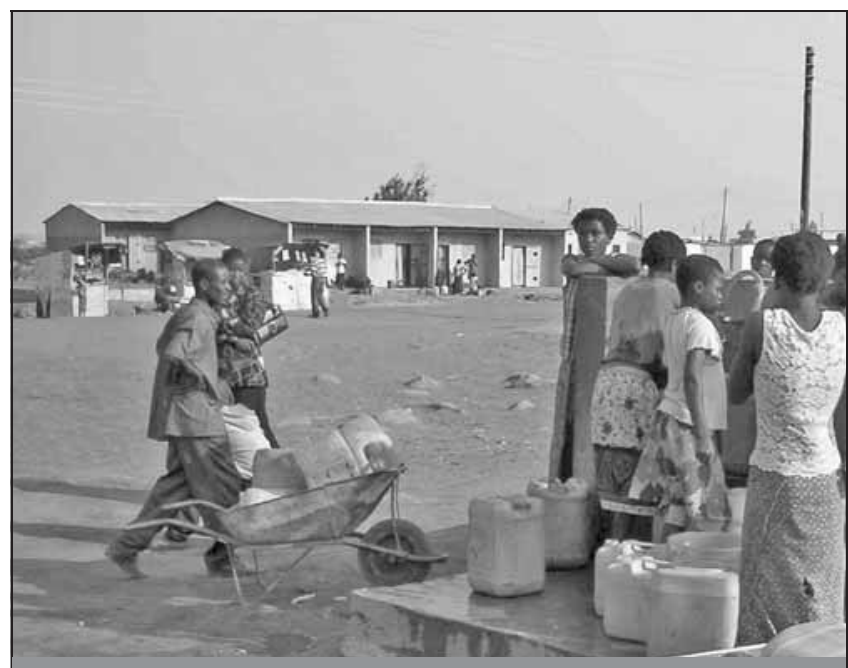

Fig. 2. One of the public tap stands managed by Kanyama Water Trust

members, drawn from partner institutions. Three members of the Board represent the RDC, a non-partisan committee composed of elected representatives of ZDCs of the compound. Others members of the Board are two directly elected members of the local community, two members from Lusaka City Council, one member from LWSC and a representative of the Ministry of Community Development and Social Services. Direct representation of community members on to the Board ensures that the voice of the community is taken into account by the highest decision-making body of the water scheme. Owing to the transient nature of members of the community, the water 


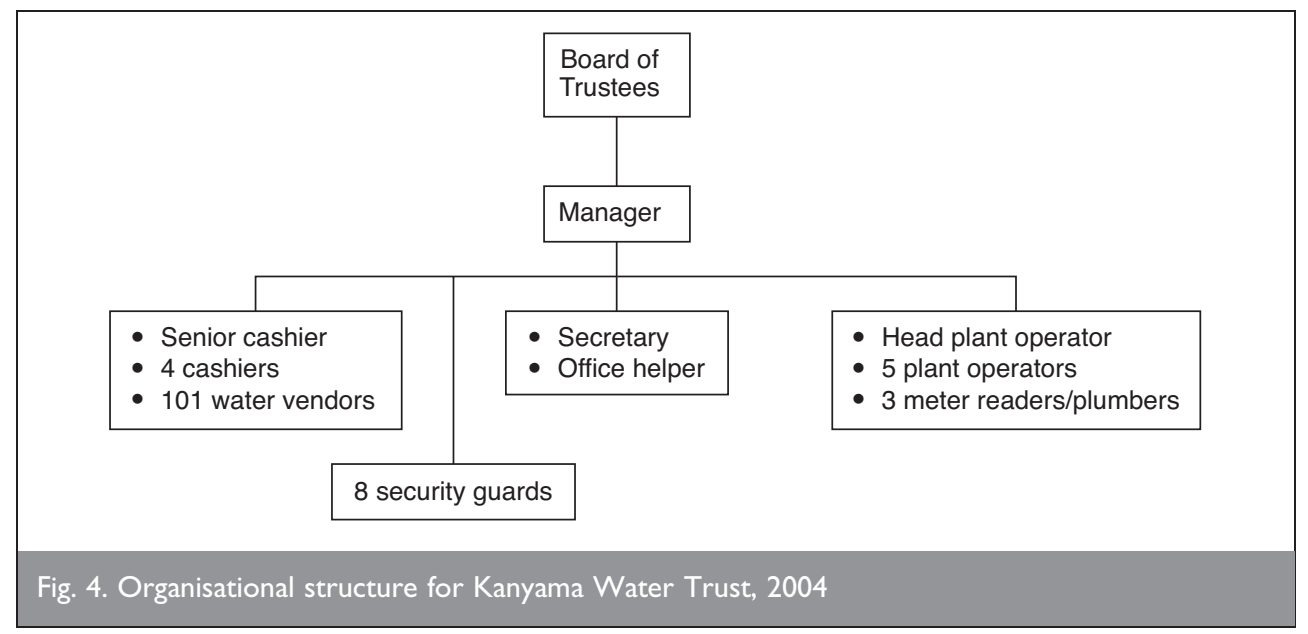

Water services are

decentralised to the four sectors of the compound. The sectors have independent water pressure zones, served by separate water abstraction, treatment/pumping, storage and distribution systems. Each sector has a plant attendant, a plumber/meter reader and a cashier, who are all employed by the Trust on a permanent basis. As shown in Fig. 4, the Trust engaged 101 water vendors on a temporary basis, who operate the public tap

scheme is legally entrusted to Lusaka City Council, although the symbolic ownership belongs to the community. According to the Water Supply and Sanitation Act (28) of $1997,{ }^{8}$ provision of water and sanitation services in Lusaka City is the mandate of LWSC. Hence, the Water Trust provides services through a partnership with LWSC. The Board members meet on a quarterly basis and receive a sitting allowance paid by the Trust.

The main role of the Board is to supervise and guide the management team, who in turn are mandated to manage the scheme on a daily basis and are required to submit regular reports to the Board. The entire staff under the management team is recruited locally through a transparent and competitive process. Once the staff take up their appointments, they are thereafter provided with relevant skills, through various capacity-building activities such as intensive courses and on-the-job training. The model allows for recruitment of vendors locally to sell water on a commission basis. In order to identify suitable vendors, PROSPECT trained more than the number needed as a way of creating a reservoir of vendors for easy replacement. Figure 4 shows the organisational chart. stands, receive revenue from the users and in turn present it to the cashiers. Table 1 shows the basic service indicators of the Water Trust in early 2005.

The priority of the Water Trust is to provide water services to community members, through public standpipes. However, since February 2004, the Trust started making individual household connections. There is a technical team that evaluates the hydraulic capacity of the system prior to approving a new household connection. Where necessary, LWSC may be contracted to provide further technical assistance. As seen in Table 1, the Water Trust has differentiated the connection charges between household and commercial use. Security fees are used to hire guards to protect the newly laid pipeline, in the wake of reported cases of vandalism in Lusaka during the first few days of a pipeline extension.

The tariff is also differentiated according to whether water is drawn from a public standpipe, or from a private house connection. All the rates set by the Water Trust are approved by the National Water Supply and Sanitation Council (NWASCO), Zambia's water services regulator, who are also expected to regulate attributes of the service delivery. However, at the time of

\begin{tabular}{|c|c|c|}
\hline Category & Service attribute & Indicator \\
\hline \multirow[t]{8}{*}{ Technical aspects } & Population served & About 85000 people \\
\hline & Water production capacity & $288 \mathrm{~m}^{3} / \mathrm{h}$ \\
\hline & Storage capacity & $400 \mathrm{~m}^{3}$ \\
\hline & Unaccounted-for water & Less than $2 \%$ \\
\hline & No. of standpipe connections & 101 \\
\hline & No. of yard-tap connections & 120 \\
\hline & Service hours & Morning: 6-II h \\
\hline & & Evening: $14-18 \mathrm{~h}$ \\
\hline \multirow[t]{3}{*}{ Commercial aspects } & Average monthly revenue collection & K8 million* \\
\hline & Collection efficiency & Over $90 \%$ \\
\hline & Operating ratio & About $80 \%$ \\
\hline \multirow[t]{8}{*}{ Cost recovery measures } & Application fees for all categories & KIO00 \\
\hline & Connection fees for domestic customers & $\mathrm{K} 100000$ \\
\hline & Connection fees for commercial customers & $\mathrm{K} 200000$ \\
\hline & Security fees for domestic customers & K30000 \\
\hline & Security fees for commercial customers & K70 000 \\
\hline & Public standpipe tariff: prepayment & K5000 per month \\
\hline & Public standpipe tariff: 'pay-as-you-go' & $\mathrm{KI} 00 / 3 \times 20$ litre containers \\
\hline & Flat rate tariff for private connections & K40000/month \\
\hline
\end{tabular}

*K: Zambian kwacha; K5000 = US\$I (July 2004) 


\begin{tabular}{|c|c|c|c|}
\hline \multirow[t]{2}{*}{ Attribute } & \multirow[t]{2}{*}{ Variable } & \multicolumn{2}{|c|}{ Frequency } \\
\hline & & $\begin{array}{l}\text { Study group } \\
(n=801): \%\end{array}$ & $\begin{array}{l}\text { Comparison group } \\
(n=300): \%\end{array}$ \\
\hline Distance travelled to the water point & Not more than $100 \mathrm{~m}$ & 74 & 29 \\
\hline How long does the round trip to collect water take? & Less than $20 \mathrm{~min}$ & 90 & 25 \\
\hline What is the price of water? & 0-K50 per 20 litre bucket & 73 & 16 \\
\hline \multirow[t]{3}{*}{ Where do you draw water for drinking/cooking? } & From the Trust water points & 94 & 0 \\
\hline & From LWSC water points & 0 & 65 \\
\hline & From shallow wells & 6 & 35 \\
\hline \multirow[t]{3}{*}{ Where do you draw water for other household chores? } & From the Trust water points & 77 & 0 \\
\hline & From LWSC water points & 0 & 63 \\
\hline & From shallow wells & 23 & 37 \\
\hline
\end{tabular}

the study, there was little evidence that the Water Trust services were being subjected to effective scrutiny. As shown in Table 1, the Trust operates a flexible bill payment system. In addition to cash payments at the tap stand, prepayment cards may be purchased at K5000 (Zambian kwacha) per month, giving an entitlement of seven 20 litre containers per household per day, which translates into a discount of about K30 per three containers. However, the 'pay-as-you-fetch' system is more popular, mainly owing to affordability limitations.

A few challenges were experienced during the implementation phase. In the first instance, some residents did not believe in the project, while others felt the coming of the project interfered with their political aspirations, as lack of water was mostly used as a campaign strategy. Second, despite considerably long periods of time spent on community mobilisation, some households did not participate in the project. Third, the transient nature of people in the peri-urban areas culminated into a high level of turnover of trained volunteers, which lengthened the implementation period. Fourth, although the beneficiaries were expected to make a contribution in terms of labour, some people expected wages for the work performed, which was not budgeted. Fifth, the majority of project participants were women, who lacked the physical capacity to carry out some tasks requiring physical strength. Finally, some of the participants had low literacy levels such that it was difficult to carry out simple artisan training on the job.

\section{EVALUATION OF WATER TRUST MANAGEMENT SYSTEMS}

CARE International carried out evaluation in mid-2004 to establish the impact of PROSPECT in the project areas. The study compared various aspects of the livelihoods of residents of three peri-urban settlements of Lusaka (Chaisa, Chibolya and Kanyama) where the project was implemented, with those of residents of Kalikiliki peri-urban settlement, which did not participate in the PROSPECT activities. The evaluation sample was composed of 801 households from the project areas and 300 households from the non-project area. Data collection techniques for the evaluation study consisted of a review of unpublished departmental and policy documents, household questionnaires, key informant interviews, focus group discussions and direct observations.

Analysis of the key socio-economic characteristics showed no significant difference between the study and the comparison groups. Seventy-three per cent of the respondents were female, although only $21 \%$ of the households were headed by a female. Most male heads of household were not at home at the time of the evaluation. Eighty-six per cent of respondents reported to have completed at least primary level basic education, with 29\% claiming to have attained at least secondary level education. About half of the sample (52\%) had a household size of not more than five people, while $39 \%$ had a household size of 6-10 people. Over three-quarters (80\%) of interviewed households reported a monthly income of between K30 000 and K623 000, most of which (K5000-456 000) was spent on food. Table 2 shows major results of the comparative evaluation study as they related to water services.

Table 2 shows that key service levels of water services provided by the Water Trust are significantly higher than levels of service delivered by LWSC. The distance travelled, the time spent collecting water, the price of water, and the amount of water used by the household are all more favourable in the peri-urban areas served by the Water Trust than the area served by the traditional water utility provider. It therefore makes social and economic sense that there is a smaller proportion of households in the project areas drawing water from shallow wells, compared to the area served by LWSC. Furthermore, 76\% of respondents from the project areas were satisfied with the level of service offered through the public tap stands. More than half of the respondents (57\%) rated the hours of operation at the public tap stands as satisfactory. However, 18\% thought the number of tap stands was inadequate and 51\% indicated that water services provided by the Water Trust were more expensive than before the advent of the project. This is not surprising, as $46 \%$ of the respondents previously obtained water from shallow wells at no fiscal charge.

\section{SUMMARY AND CONCLUSION}

Lusaka Water and Sewerage Corporation, a public liability company wholly owned by Lusaka City Council, is legally responsible for provision of water and sanitation services to all residents of Lusaka City. However, service levels provided by the water utility are inadequate, in the wake of poor efficiency levels as reflected by a high 'unaccounted-for' water of 58\%, alongside the proliferation of informal and unplanned settlements. At the time of this fieldwork in July 2004, service coverage was estimated at $34 \%$ of the city population, and attributes such as service continuity and reliability were not much better. The situation is not peculiar to Lusaka: research carried out in many low-income countries suggests that full service coverage through 
conventional utility providers is unlikely to be achieved in the short or medium term under present arrangements. ${ }^{11}$

Water Trusts, set up by CARE International through the PROSPECT project, have plugged the water service gap in Lusaka and Livingstone cities in Zambia. Over a five-year project period, PROSPECT, in partnership with Lusaka City Council and LWSC, developed the organisational capacity of communities in 13 peri-urban settlements, with an estimated population of 600000 people, and facilitated the formation of Water Trusts, which are currently providing water services to residents in these low-income settlements. Evaluation of the community-managed Water Trusts carried out in mid-2004 showed that the majority of service recipients were satisfied with the level of service in terms of reliability, continuity, customer relations, price and flexibility of payment methods. However, at the time of the study, there was no evidence of direct contact between the Water Trust and the Regulator. Therefore, there is a need to explore the optimum institutional arrangement to ensure that communities served by the Water Trust fully benefit from the water services regulatory systems.

Community management may not be a long-term management solution in provision of urban water services, mainly owing to the transient nature of community members and inadequate organisational capacity for scaling up operations. ${ }^{7}$ However, what this case study demonstrates is that partnerships between NGOs, communities and water utility providers are capable of adequately bridging the service gap, to the extent of even providing better service levels than conventional water utility providers, at least in the short to medium terms. This mode of service delivery is qualitatively better than diversified small-scale intermediate service providers that are a common feature in many low-income cities, who present more challenges for service quality regulation. ${ }^{11}$

\section{ACKNOWLEDGEMENTS}

This paper is a subsidiary outcome of fieldwork carried out under the Engineering Knowledge and Research Contract R8320 funded by the UK Department for International Development (DfID). The views expressed are not necessarily those of DfID.

\section{REFERENCES}

1. Cosgrove, W. and Rijsberman, F. World Water Vision: Making Water Everybody's Business. Earthscan Publications, London, 2000.

2. World Health Organisation/UNICEF (United Nations CHILDREN's Fund, formerly UnITED NATIONS INTERNATIONAL Children's Emergency Fund). Global Water Supply and Sanitation Assessment Report 2000. WHO, Geneva, 2000.

3. Collignon, B. The Public Water Service for Disadvantaged People. Villes en d'eveloppement: Efficiency of Urban Services. World Bank, Washington DC, 1998.

4. BRoCKLEHURST, C. Local Management Models for Water Supply and Sanitation for the Urban Poor, Workshop Proceedings for Building Partners for Development in Water and Sanitation (BPD), London, 2004. See http:// www.bpdws.org/bpd/web/d/doc_58.pdf for further details (accessed on 30 May 2006).

5. Government of the Republic of Zambia, Ministry of Local Government. Peri-Urban Water Supply and Sanitation Strategy. Unpublished policy document, Government of the Republic of Zambia, Lusaka, 2001.

6. Lusaka Water and Sewerage Company. Peri-Urban Unit Operational Report June 2004. Unpublished organisational report, LWSC, Lusaka, 2004.

7. National Water Supply and Sanitation Council (NWASCO). Urban and Peri-Urban Water Supply and Sanitation Sector Report 2002/2003. NWASCO, Lusaka, 2004.

8. Government of the Republic of Zambia. Water Supply and Sanitation Act (28). Government of the Republic of Zambia, Lusaka, 1997.

9. CARE-Programme of SuPPORT For POVERTy Elimination AND COMMUNITY TRANSFORMATION (PROSPECT). Basic Performance Indicators for Water Trusts. Unpublished organisational report, CARE, Lusaka, 2005.

10. CARE-Programme of Support for POVERTy Elimination AND Community TRANSFORMATION (PROSPECT). Livelihood Assessment in the CARE-PROSPECT Project Areas. Unpublished research report, CARE, Lusaka, 2004.

11. Collignon, B. and Vezina, M. Independent Water and Sanitation Providers in African Cities: Full Report of a Ten-country Study. UNDP-World Bank Water and Sanitation Program, Washington DC, 2000.

\section{What do you think?}

To comment on this paper, please email up to 500 words to the editor at journals@ice.org.uk

Proceedings journals rely entirely on contributions sent in by civil engineers and related professionals, academics and students. Papers should be 2000-5000 words long, with adequate illustrations and references. Please visit www.thomastelford.com/journals for author guidelines and further details. 